\title{
粗
}

\section{Gebed in die lewe van Jesus volgens die Lukas-evangelie}

F.P. Viljoen

Skool vir Bybelwetenskappe en Bybeltale

Potchefstroomkampus

Noordwes-Universiteit

POTCHEFSTROOM

E-pos: sbbfpv@puk.ac.za

\section{Abstract}

Prayer in the life of Jesus according to the Lucan Gospel

Prayer materials in Luke's Gospel are rich and unique. In this article passages related to Jesus' prayer life are explored. According to Luke, Jesus' prayer life is aligned with salvation history. Jesus' prayers are solemn acts to focus his life on the will of God and to be empowered by the Holy Spirit. Furthermore Jesus' prayers are constantly associated with the cross, by which salvation history reaches its culmination and the Kingdom of God is established. As Jesus prepared his way through prayer, so his disciples are to pray during the period after his resurrection and ascension in their awaiting of the parousia.

\section{Opsomming}

Gebed in die lewe van Jesus volgens die Lukas-evangelie

Gebedsmateriaal in die Lukas-evangelie is ryk en uniek. In hierdie artikel word gedeeltes wat oor Jesus se gebedslewe handel, ondersoek. Volgens Lukas staan Jesus se gebedslewe in verband met heilsgeskiedenis. Jesus se gebede is plegtige handelinge waardeur Hy sy lewe op die wil van God rig en om deur die Heilige Gees bekragtig te word. Daarbenewens is sy gebede deurgaans geasosieer met die kruis, waardeur die heilsgeskiedenis sy kulminasie bereik en die Koninkryk van God gevestig word. Soos wat Jesus sy weg deur gebed voorberei het, so behoort sy dissipels ook te bid in die tydvak na sy opstanding en hemelvaart in afwagting van die parousia. 


\section{Inleiding}

Gebed vorm 'n besondere motief in die Lukas-evangelie. Dit raak sowel die frekwensie, terminologie en verband waarbinne daar oor die gebed gehandel word en dat heelwat van hierdie besonderhede net in Lukas voorkom. Ott (1965:13) merk tereg op dat Lukas die evangelis van gebed genoem kan word.

Die hoë frekwensie van die gebruik van gebedsterme is opvallend (Conn, 1972:290; Han, 2000:675; Morris, 1990:213; Smalley, 1973: 59). Van die 68 keer wat die terme $\pi \rho 0 \sigma \epsilon u ́ x o \mu \alpha \iota$ en $\pi \rho 0 \sigma \epsilon u ́ x \eta$ in die Nuwe Testament gebruik word, kom dit 35 keer in die Lukaanse geskrifte (Lukas en Handelinge) voor en 22 keer in die Evangelie as

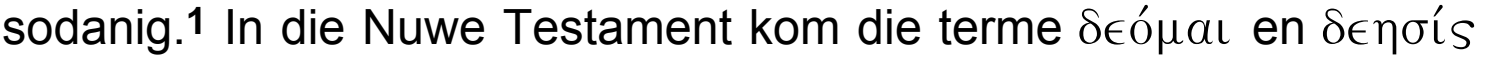
34 keer voor. Lukas gebruik hierdie terme 19 keer, ${ }^{2}$ waarvan agt keer in die Evangelie. Hierbenewens gebruik Lukas ook die woorde

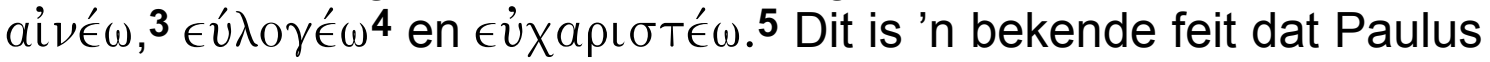
in paranetiese en didaktiese kontekste dikwels oor gebed handel. Nogtans is daar kwantitatief meer kere deur Lukas oor gebed geskryf (O’Brien, 1973:113).

Plummer het reeds teen die einde van die negentiende eeu daarop gewys dat gebed 'n groter rol speel in Lukas as in die ander Evangelies. Hy onderskei twee fasette: die voorbeeld van Jesus se gebedslewe en sy onderrig oor die gebed (1896:xlv).

Benewens die hoë frekwensie van bogenoemde terme in die Evangelie, is dit opvallend dat die meeste van die materiaal oor die gebed in die Evangelie uniek is aan Lukas (Carson, Moo \& Morris, 1992:131; Conn, 1972:290; Smalley, 1973:59). Voorbeelde van Lukas Sondergut oor gebed is:

- Jesus het gebid terwyl Hy gedoop is (3:21);

- Hy het heelnag gebid voor die roeping van die twaalf $(6: 12)$;

$1 \quad$ Lukas 1:10; 3:21; 5:16; 6:12, 28, 29; 11:1 (twee maal), 2; 18:1, 10, 11; 20:47; $22: 40,44,46$. Die kognate selfstandige naamwoord is gebruik in 6:12; 19:46 en $22: 45$.

$2 \delta \in$ ó $\mu a \iota$ agt keer in die Evangelie (sewe keer in Handelinge); $\delta € \eta \sigma i ́ s$ drie keer.

3 Drie keer in die Evangelie en drie keer in Handelinge.

$4 \quad$ Dertien keer in die Evangelie en twee keer in Handelinge.

$5 \quad$ Vier keer in die Evangelie en twee keer in Handelinge. 
- Jesus het in Caesarea Filippi gebid voor die belydenis van Petrus (9:18);

- Jesus het Petrus en Johannes saamgeneem toe Hy gaan bid het op die berg van verheerliking (9:28);

- Jesus se gebed vir Simon Petrus dat die Satan hom nie sou sif nie (22:31-32);

- Hy het by sy dissipels aangedring om te bid met die oog op die toekoms (21:36); en

- Hy het twee keer aan die kruis gebid $(23: 34,46)$.

Hierbenewens is dit net Lukas wat die uitgebreide weergawe bied van Jesus se onderrig oor die gebed deur middel van gelykenisse, wat gevolg is deur die versoek van sy dissipels, "Here, leer ons bid" (11:1-13; 18:1-14). Hierbenewens toon Harris (1966:21) aan dat Lukas "has sixteen prayer terms where his sources do not" en ook "these terms appear at significant points in his Gospel".

Die Evangelie begin deur te verwys na die gebed van die volksmenigte (1:10) en eindig met die gelowiges wat met groot blydskap die Here aanbid (24:52 en 53) (Viljoen, 2003:207). Benewens die verwysing na die gebede van die groepe gelowiges, word daar ook herhaaldelik verwys na die gebede van individue, byvoorbeeld Sagaria (1:13) en die profetes Anna (2:37).

Die gebede van Jesus volg 'n baie sterk motief deur die loop van die Evangelie. Dit wil voorkom asof die gebede van Jesus 'n besondere rol speel by belangrike keerpunte in die verhaal (Conn, 1972:290; Groenewald, 1989:62). Dit blyk onder andere uit die volgende beskrywings van Lukas:

- Die hemel het oopgegaan terwyl Jesus gebid het tydens sy doop $(3: 21)$;

- Jesus het gebid voor sy vraag aan die dissipels: "Wie, sê die mense, is Ek?" (9:18);

- Jesus het vir Petrus, Jakobus en Johannes saamgeneem om te gaan bid, net voor sy verheerliking op die berg (9:28-29);

- Sy dissipels het Hom gevra om hulle te leer bid (11:1);

- Die gelykenis van die vriend wat vir brood smeek om middernag $(11: 5-8)$;

- Die gebed van Jesus vir Petrus dat die Satan hom nie sal sif nie (22:21 en 32); en 
- Jesus gee die dissipels opdrag om te bid toe hulle in Getsemane aankom (22:40).

Ott (1965:60) toon aan dat gebed 'n belangrike funksie het in die oorkoepelende skema van Lukas en Handelinge. Jesus het deurlopend gebid en het 'n beroep op sy dissipels gedoen om dieselfde te doen. Harris (1966:98) en Conn (1972:6) argumenteer dat Lukas gebed beskou het as 'n belangrike middel waarmee God die koers van die heilsgeskiedenis bepaal. Hulle voer aan dat gebede nou verwant is aan belangrike momente in die Heilsgeschichte. "The primary significance of prayer in Luke's thought is that it serves as an important way in which the divine plan of salvation is made known" (Harris, 1966:208).

'n Soortgelyke prominensie van gebed kom ook voor in Lukas se tweede geskrif, Handelinge. Handelinge begin byvoorbeeld met die gelowiges wat eendragtig volhard het in die gebed (1:14), hulle gebed voor die aanwys van Mattias (1:24). Verder is beskryf hoe die kerk gebid het onder vervolging (4:24-31), hoe Stefanus die gebed van Jesus aan die kruis ge-eggo het toe hy gestenig is (7:59), hoe daar gebid is aan die begin van die sending onder die heidene (6:6), hoe die nuwe gelowiges in Samaria die Heilige Gees ontvang het in antwoord op die gebede van Petrus en Johannes (8:15-17) en hoe die gelowiges gebid het voor Paulus se sendingreis (13:3).

Dit is duidelik dat gebed 'n baie prominente motief vorm in Lukas se geskrifte, die Lukas-evangelie en Handelinge. In 'n bespreking van gebed volgens Lukas sou verskeie sake aandag verdien. Uiteraard moes die tema vir die doel van hierdie artikel afgegrens word. In die eerste plek word net die eerste boek van Lukas (die Lukasevangelie) behandel. Voorts word daar net ondersoek ingestel na die gebede van Jesus as sodanig. Tekste waar mense bid of Jesus onderrig gee oor die gebed, val buite die bestek van hierdie ondersoek.

Die doel van hierdie artikel is om te bepaal waarom Lukas in die Evangelie soveel prominensie aan die gebede van Jesus verleen. Benewens die feit dat Lukas 'n historikus was, het hy op 'n organiese manier ook 'n persoonlike benadering gehad in sy aanbieding van die vertelling (Viljoen, 2003:199). 'n Mens sou daarom kan verwag dat Lukas se beklemtoning die gevolg is van sy eie interpretasie en redaksie van die gebeure. 6

6 Hierdie stelling impliseer dat die Heilige Gees Lukas op 'n organiese manier geïnspireer het. 


\section{Gebed in die lewe van Jesus}

"Door niets wordt de betekenis van het gebed duidelijker onderstreept dan door het feit, dat Jezus tijdens zijn omwandeling op aarde aan het gebed een grote plaats gaf' (Versteeg, 1991:9). Verskillende tekste wat oor Jesus se gebedslewe handel, word vervolgens behandel. Opmerklik is dat die meeste hiervan deel vorm van die sogenaamde Lukas Sondergut wat Lukas se besondere klem op die gebed aantoon.

\subsection{Lukas 3:21-22 (By Jesus se doop)}

Toe al die mense hulle laat doop het, is Jesus ook gedoop, en terwyl Hy staan en bid, het die hemel oopgegaan en het die Heilige Gees in sigbare gestalte soos 'n duif op Hom neergedaal. Daar was ook 'n stem uit die hemel: "Jy is my geliefde Seun. Oor Jou verheug Ek My."7

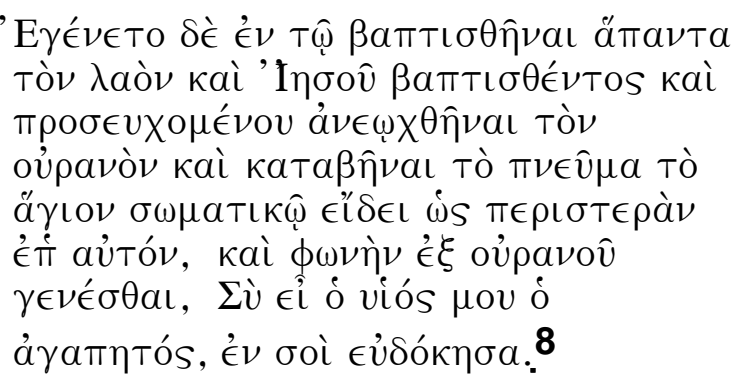

In hierdie verse kom die eerste verwysing na Jesus se gebedslewe voor. Hierdie gebeurtenis lui sy openbare optrede in. Opvallend is die gebruik van die praesens deelwoord in die genitief absolute konstruksie vir die bidhandeling $(\pi \rho 0 \sigma \in v \chi o ́ \mu \epsilon \nu 0 v)$. Hieruit blyk dit dat Jesus na sy doop begin bid het en aangehou het tot die Heilige Gees op Hom neergedaal het en die stem uit die hemel gekom het (vgl. Han, 2000:679). "Jezus kwam bidden tot de aanvaarding van zijn roeping” (Versteeg, 1991:10). Die neerdaling van die Heilige Gees geskied volgens Lukas nie met die doop nie, aangesien daardie handeling toe reeds afgehandel was (O'Brien, 1973:114). Dit is in ooreenstemming met ander gedeeltes in Lukas waar die Heilige Gees gegee word in antwoord op gebede (Luk. 11:13; Hand. $1: 14$ in samehang met $2: 1-4 ; 4: 23-31$ en $8: 15-17)$.

Al drie die Sinoptiese Evangelies berig dat die Heilige Gees neergedaal het gedurende Jesus se doop. Dit is egter net Lukas wat

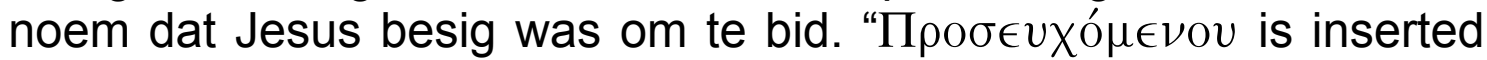
from Luke's enthusiasm for prayer" (Goulder, 1994:281). Volgens Lukas is gebed baie nou verbind aan die Heilige Gees (Floor, 1988:22; Morris, 1990:192; Versteeg, 1988:310; Won, 1999:47).

$7 \quad$ Volgens die 1983-Afrikaanse vertaling.

$8 \quad$ Volgens die UBS-3 teks. 
Lukas gebruik die teenwoordige deelwoord $\pi \rho \circ \sigma \in v \chi O ́ \mu \epsilon \nu$ ov (terwyl $\mathrm{Hy}$ bid) en kontras met die aoristus $\beta a \pi \tau \iota \sigma \theta \epsilon ́ \nu \tau O S$ (gedoop), om aan te toon dat die Heilige Gees op Jesus neergedaal het, terwyl Hy besig was om te bid. Die parallel met Handelinge is opvallend. Soos wat Jesus gebid het en op grond daarvan toegerus is vir sy bediening wat sou volg, beskryf Lukas hoe die vroeë kerk ook gebid het vir toerusting vir hulle dienswerk (Hand. 1:14 in samehang met 2:4). Dit was in gebed dat die kerk, soos Jesus met sy doop, gewag het op die koms van die Heilige Gees.

Lukas verbind die werk van die Heilige Gees aan gebed (Blomberg, 2002:149; Scheffler, 1991:74). Lampe (1955:169) beskryf hierdie verhouding as "one of the most characteristic features of St. Luke's teaching" en gebed as "the means by which the dynamic energy of the Spirit is apprehended". Lukas beskryf gebed as komplementêr tot die Heilige Gees se aktiwiteit, aangesien dit die punt is waar die kommunikasie van Goddelike invloed effektief raak vir die ontvangers. Gebed is die manier waarop die bidder onder beheer kom van die Gees se krag en invloed. Die gawe van die Heilige Gees is God se primêre gawe in antwoord op 'n mens se gebed "Hy sal die Heilige Gees gee vir dié wat vra" (Luk. 11:13)9

'n Ondersoek na die Ou-Testamentiese agtergrond vir die woorde uit die hemel ("Jy is my geliefde Seun. Oor Jou verheug Ek My."), werp lig op die betekenis van hierdie gebed van Jesus. Die woorde staan bekend as die bath qol en is ontleen van die koningspsalm, Psalm 2:7 ("Jy is my seun, vandag het Ek jou Vader geword") (Smalley, 1973:65). Hieruit blyk dat die doop van Jesus beskou moet word as die inaugurering van die Messiaskoning (Floor, 1988:23; Nolland, 1989:163; Tuckett, 2001:316). Die doop van Jesus met die Gees is die groot datum in die koms van die koninkryk (Snyman:1977:200). 10

Die stem herinner egter ook aan Jesaja 42:1 "Hier is my dienaar, Ek stel hom aan. Ek het hom uitverkies, hy geniet my guns. Ek laat my Gees op hom kom", waar dit oor die lydende kneg handel. Die stem uit die hemel beskryf daarom ook dat Jesus se doop Hom aanwys as die lydende Kneg. Hoewel die Messias die eer van die Seun van God uitbeeld, moet Hy ook die afgryslike lyding deurmaak tydens sy

9 "Lucas hat entsprechend v. 2 als eigentlichen Inhalt des christlichen Gebets und höchste Gabe den Geist genannt" (Klostermann, 1929:126).

10 Dunn (1970-71:36) toon aan dat Lukas die verhouding tussen die koninkryk en die Heilige Gees beklemtoon. 
aardse lewe en sterwe (vgl. Viljoen, 2002:461). "De heerlijkheid van het zoonschap gaat over de weg van de lijdende knecht des Heren" (Berkelbach van der Sprenkel, 1964:54). Met hierdie stem is Jesus in die middelaarsamp gestel. Sy dienswerk as tussenpersoon tussen God en die mens begin nou duidelik word. Die doop is die begin van Jesus se optrede wat moet uitloop op die kruis en opstanding. Jesus kom as Verlosser van die mensdom in nood (Viljoen, 2003:207).

Hierdie gebed van Jesus open eskatologiese perspektief. Die proses van die koms van die koninkryk begin. Eskatologiese perspektief in gebed is 'n belangrike eienskap by die OuTestamentiese profete. Die profete beskryf die koms van die koninkryk as die tyd wanneer gebede beantwoord word (Conn, 1972:290). Jesaja het gesê dat God Israel se gebede nie meer hoor nie: "Selfs al bid julle hoe baie, sal Ek nie luister nie, want julle hande is met bloed bevlek" (Jes. 1:15 - vgl. ook Jes. 59:2). Benewens sedelike onreinheid, is God se volk nie meer beskou as 'n koninkryk van priesters nie. Daarom sou God 'n ware priester stuur. Wanneer Hy sou kom, sou daar 'n nuwe begin vir gebed wees. God sou weer sy volk kom opsoek om opnuut 'n paradys te skep. "Ek gaan 'n nuwe hemel en 'n nuwe aarde skep" (Jes. 65:17). "Voor hulle nog roep sal Ek antwoord, terwyl hulle nog praat, sal Ek hulle gebed verhoor. Die wolf en die lam sal saam wei, die leeu sal strooi vreet soos 'n bees ..." (Jes. 65:24-25). In hierdie nuwe hemel en nuwe aarde sal almal tot die Here bid en Hom prys: "want my tempel sal uitgeroep word tot 'n huis van gebed vir al die volke" (Jes. 56:7).

Volgens Lukas se beskrywing, het hierdie groot dag aangebreek. Die dag breek aan met die gebed van Jesus. Die duif simboliseer 'n nuwe eskatologiese begin (soos in Gen. 8:8). Die hemele is geopen. Dit is 'n teken van dialoog tussen God en die mensdom (Conn, 1972:291).

Direk na hierdie gebeure word Jesus deur die Gees uitgelei na die woestyn waar Hy deur die Satan versoek word. Hierdie Messiaanse stryd staan binne die konteks van gebed.

\subsection{Lukas 5:16 (Jesus se gereelde gebed)}

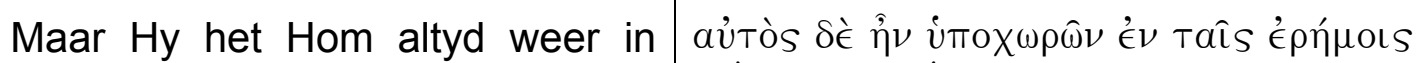

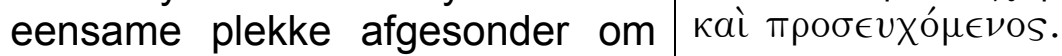
daar te bid. 
In die voorafgaande verse word die entoesiasme en verwagting van die menigtes beskryf na Jesus se genesing van 'n melaatse. Marshall voer aan dat Jesus Hom doelbewus teruggetrek het om te voorkom dat die massas van Hom "their popular idol or even their servant" (1978:210) maak. Die gebruik van Jesus om Hom vir gebed af te sonder, hou egter meer in as om hierdie misplaaste verwagting van die massas te vermy. Volgens Lukas het Jesus Hom gereeld teruggetrek in stil plekke vir gebed. Hoewel al drie die Sinoptiese Evangelies na die genesing van die melaatse verwys en dat Jesus Hom afgesonder het, is dit net Lukas wat beskryf dat Jesus tydens sy afsondering gebid het. Goulder skryf: "Luke believes in prayer, and takes advantage of the repeated withdrawal to the desert to include it here" (1994:330). Op grond van die teenwoordige tyd van die deelwoord $\pi \rho \circ \sigma \in \cup \chi O ́ \mu \epsilon \nu$ os blyk dit dat dit Jesus se gebruik was om Hom in gebed af te sonder.

In sy omgang met die Vader het Hy telkens leiding gevind vir die volgende stap en daar ook die krag geput om met Goddelike gesag op te tree (Groenewald, 1989:81). Danker (1988:120) toon aan dat dit ook in hierdie omstandighede die geval was. Jesus se afsondering het te doen gehad met sy voorbereiding vir dit wat voorgelê het. Volgens Rengstorf (1965:76): "Hier, im Umgang mit Gott, liegen die Motive seines Wirkens und die Wurzeln seiner Kraft". Jesus sou binnekort 'n reeks konfliksituasies moes konfronteer, die genesing van die verlamde man (5:17-26), teenkanting toe Jesus by Levi gaan eet het, die konflik oor die onderhouding van die Sabbat (6:1-5) en Jesus se genesing van die man met die gebreklike hand, wat die skrifgeleerdes en Fariseërs rasend van woede gemaak het $(6: 1-11)$. Hieroor het hulle geredeneer wat hulle Jesus sou aandoen. Die skadu van die kruis word al sigbaar. Lukas toon aan dat Jesus daarom homself vooraf eers in gebed met God afgesonder het en hom voorberei om die kruis op te neem (Han, 2000:681). Lukas onderstreep hoe Jesus se verbondenheid aan die Vader deur gebedsgemeenskap Hom voorberei het vir sy lewenswerk.

Uit hierdie beskrywing kom die tweevoudige verbondenheid van Jesus na vore, sy verbondenheid met die Vader en dié met die mense. Die eerste beheers die tweede en vorm die beheerkrag daarvan. 


\subsection{Lukas 6:12 (Voor die roeping van die twaalf)}

\begin{tabular}{|c|c|}
\hline $\begin{array}{l}\text { In daardie tyd het Jesus uitgegaan na } \\
\text { die berg toe om te bid en die hele nag } \\
\text { deurgebring in gebed tot God. }\end{array}$ & 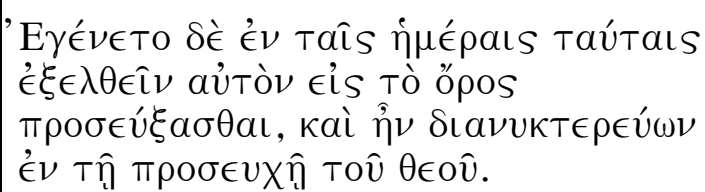 \\
\hline
\end{tabular}

Dit wil voorkom asof hierdie vers saam met 5:16 'n omraming vorm van die konfliksituasies wat daarbinne beskryf is. Tussen hierdie twee verse word die groeiende spanning tussen Jesus en sy opponente beskryf, wat sy klimaks bereik in 6:11. Lukas 6:12 vertel daarna van Jesus se gebed, terwyl Jesus in lewensgevaar verkeer het.

Hierbenewens is die gebed ook direk betrokke by die roeping van die twaalf dissipels wat in 6:13-16 beskryf is. Die beskrywing van die gebed voor die roeping van die twaalf kom net in die Lukasevangelie voor. Hierdeur beklemtoon Lukas die "momentous issues of the choice which was to be made" (O'Brien, 1973:115). Rengstorf (1965:83) kommentarieer ook : "Wenn es heisst, er habe die der Wahl vorausgehende Nacht im Gebet verbracht ..., so beleuchtet das die Wichtigkeit seiner Entscheidung". Die twaalf word geroep om die redding, wat die koms van die koninkryk bied, hier en nou te verkondig. "Prayer is a practice dear to Luke, and Jesus will surely have been deep in prayer before choosing his Twelve. All-night prayer is specific to Luke ... with Anna (2:37), God's elect (18:7), and 'our twelve tribes' (Acts 26:7)" (Goulder, 1994:341).

Lukas plaas besondere klem op die gewigtige situasie (Van Bruggen, 1996:151). Dit is net hier dat Lukas beskryf dat Jesus die hele nag in gebed deurgebring het (Nolland, 1989:269). Die keuse van die twaalf is die gevolg en vrug van Jesus se gebedsnag. Jesus het na die berg gegaan om in die donker en eensaamheid te konsentreer op sy verbondheid met God. "Vanuit deze gebedsnacht wordt het nieuwe geheel, dat later 'kerk' zal genoemd worden, geboren" (Berkelbach van der Sprenkel, 1964:101). Die dissipels sou ook, soos Lukas dit uitdruklik stel (6:12), Jesus se apostels wees. Die apostels sou sy gevolmatigde afgesante in hierdie wêreld word (Versteeg, 1991:11).

Die bedreiging van die kruis val ook reeds op hierdie gebed van Jesus met die oog op die roeping van die twaalf. Die name van die twaalf dissipels word genoem, maar by die naam van Judas Iskariot volg direk "wat die verraaier geword het" (6:16). Lukas toon aan dat 
hierdie gebed van Jesus 'n antisipasie is van die verraad van Judas wat tot die kruisiging sou lei (Han, 2000:682).

\subsection{Lukas 9:18-27 (By Petrus se belydenis)}

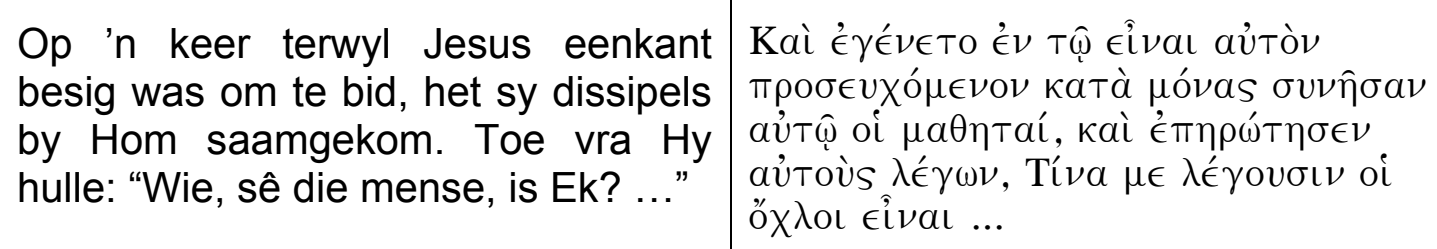

Lukas plaas ' $n$ uiters belangrike moment in die bediening van Jesus, die belydenis van Petrus, binne die konteks van gebed. Weer eens is dit net Lukas wat beskryf dat Jesus besig was om te bid, by hierdie gebeure. Jesus het Hom afgesonder vir persoonlike gebed. Hieruit blyk weereens Lukas se besondere klem en interpretasie van Jesus se gebed.

In vergelyking met Markus se weergawe van dieselfde gebeurtenis bestaan daar die volgende voor die hand liggende verskille.

- In die eerste plek laat Lukas Petrus se foutiewe verset en Jesus se teregwysing uit (vgl. Markus 8:32-33). In plaas daarvan om Petrus se fout uit te lig, wil Lukas klaarblyklik eerder die klem daarop lê dat Jesus se gebed die effek gehad het dat Petrus tot so 'n besondere belydenis oor die "Gesalfde van God" (9:21) kon kom.

- Ellis (1966:139) wys daarop dat Lukas hiermee aantoon hoe die vroeëre profesie van die Here vervul word: "Aan julle is dit gegee om die geheime van die koninkryk van God te ken" (Luk. 8:10). Volgens Lukas kon Jesus op grond van hierdie belydenis voortgaan om hulle oor die eise van dissipelskap te leer.

- Jesus sluit hierdie onderrig af met sy uitspraak oor die koms van die koninkryk: "Daar is party van dié wat hier staan wat beslis nie sal sterf voordat hulle die koninkryk van God gesien het nie" (Luk. 9:27). Die gedeelte begin met gebed en eindig met die koninkryk. Daartussen staan Petrus se belydenis, Jesus se eerste aankondiging van sy lyding en onderrig oor dissipelskap.

Al drie hierdie dele het te doen met die kruis. Jesus se gebed vorm deel van sy voorbereiding om die lyding van die kruis te kan deurmaak (Han, 2000:683). 
Jesus se gebed staan in verband met die koms van die koninkryk en die opneem van die kruis deur Jesus. Dit vorm ook 'n patroon vir sy dissipels (Danker, 1988:114; Marshall, 1978:378). Noudat Petrus dit uitgespreek het dat Jesus die Christus is, staan die dissipels ook onder die verpligting om Hom end-uit te volg (Groenewald, 1989:128). Dit is nie 'n maklike weg nie. Dissipelskap is veeleisend, en gebed is nodig om daarmee te kan volhou.

\subsection{Lukas 9:28-36 (Op die berg van verheerliking)}

\begin{tabular}{|c|c|}
\hline $\begin{array}{l}\text { Omtrent ag dae nadat Jesus hierdie } \\
\text { woorde gesê het, het Hy vir Petrus en } \\
\text { Johannes en Jakobus saamgeneem } \\
\text { die berg op om te gaan bid. Terwyl Hy } \\
\text { bid, het die voorkoms van sy gesig } \\
\text { anders geword en sy klere skitterend } \\
\text { wit... }\end{array}$ & 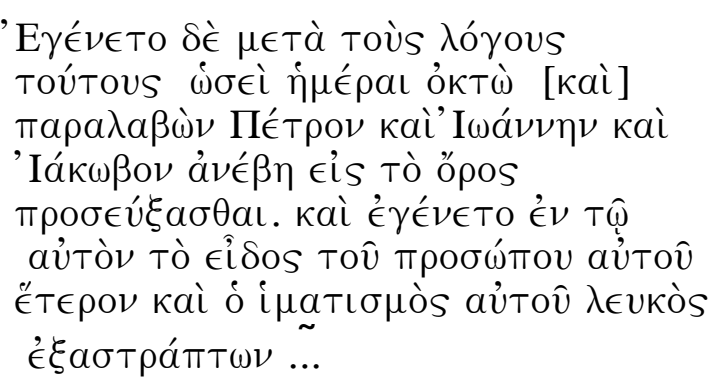 \\
\hline
\end{tabular}

Soos in Markus en Matteus, volg die verheerliking na die belydenis van Petrus ook in Lukas. Na die belydenis van Petrus word die voller waarheid deur God se stem uit die wolk van goddelike heerlikheid geopenbaar: "Dit is my Seun wat Ek uitverkies het. Luister na Hom" (9:35). Op so 'n manier word Petrus se insig bevestig en verdiep deur die hoogste gesag (Goulder, 1994:441).

Bykomend tot dit wat Markus berig, is dit opvallend dat Lukas ook die verheerliking in verband met die gereelde gebed van Jesus

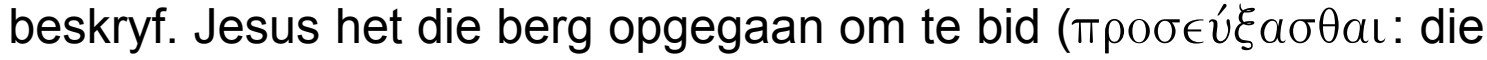
infinitief dui die doel aan) - soortgelyk aan wat in Lukas 6:12 berig is. Die opgaan teen die berg herinner aan Eksodus 24 waar Moses die berg Sinaï opgegaan het om die Here te ontmoet. Dit was Jesus se gewoonte om by belangrike gebeurtenisse en voor groot beslissings Hom in gebed af te sonder (Groenewald, 1989:132; Nolland, 1993(a):497). Direk daarna volg dat Jesus verheerlik is terwyl Hy aan die bid was (let op die teenwoordige tyd $\pi \rho 0 \sigma \in \hat{v} \chi \in \sigma \theta a \mathrm{~L})$. Dit is asof die verheerliking plaasgevind het as

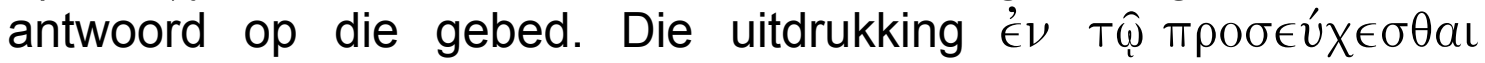
aủTòv (terwyl Hy aan die bid was), sê meer as dat Hy bloot 'n gebed uitgespreek het. Dit dui op 'n langdurige versonke wees in gebed (Berkelbach van der Sprenkel, 1964:170).

Onmiddellik volg die frase dat sy voorkoms verander het. Terwyl Jesus besig was om te bid, het sy gesig anders geword en sy klere skitterend wit. Die heerlikheid kom oor die biddende Jesus. Sy 
voorkoms laat 'n mens dink aan dié van 'n priester wat tydens sy diens in die tempel in wit geklee is, en aan engeleverskyning.

Anders as in Markus se weergawe (9:2-8) voeg Lukas bepaalde gesprekke in. Jesus voer dié gesprekke onderskeidelik met Elia en Moses en met sy dissipels. Met sy dissipels kom sy uittog ( $\epsilon$ l $\sigma \circ \delta \circ S)$ aan die orde, die uittog wat Jesus in Jerusalem sou voltooi (Luk. 9:31). Marshall beskou hierdie uittog as "the entire death-parousia career of Jesus" (1978:385), hoewel dit wil voorkom asof die klem meer op sy dood dui. Net soos Israel sy uittog (eksodus) deur die woestyn heen gehad het, sou Jesus ook 'n uittog deur die dood heen moes volbring in Jerusalem (Groenewald, 1989:133; Tuckett, 2001:314). Lukas beskryf weereens die gebed van Jesus in verband met sy lyding wat sal uitloop op sy heerlikheid (Conn, 1972:291; Han, 2000:684). Die stem uit die hemel eggo die stem by Jesus se doop, waar ook reeds sowel Jesus se dood en lyding as sy heerlikheid geïmpliseer was.

Die Heilige Gees word implisiet beskryf deur die verwysing na die wolk wat 'n skaduwee oor hulle gegooi het en hulle toe ingesluit het (9:34, vgl. Eks. 19:16-18). Daarna volg die stem uit die wolk wat verwys na die stem by die doop van Jesus (3:21-22). Die konsep van die koninkryk wat besig is om gestalte te kry, blyk uit die verheerliking en die bath qol wat Psalm 2:7 eggo.

\subsection{Lukas 22:32 (Voorbidding vir Petrus)}

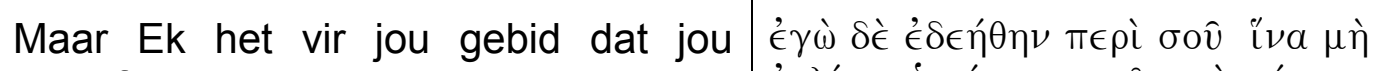

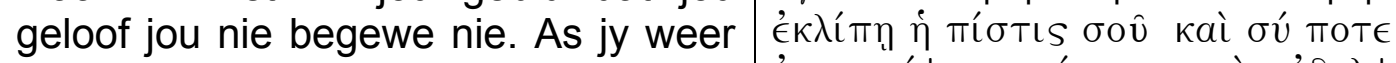
tot inkeer gekom het, moet jy jou broers versterk.

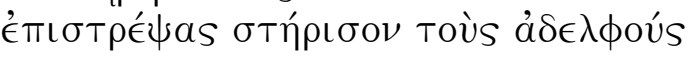
$\sigma o v$.

In hierdie priesterlike intrede vir Simon Petrus, blyk die ontsettende stryd wat vir Jesus en sy dissipels voorlê. Die vertelling van Lukas bied ' $n$ voorskou van die kruis en die mislukking van Petrus. Jesus spreek Petrus aan as verteenwoordiger van die twaalf, maar noem hom op sy vroeëre noemnaam, Simon, en Hy beklemtoon die naam deur dit te herhaal. In dié naam lê die waarskuwing teen die menslike swakheid (Groenewald, 1989:249). Dit was juis die oormoedigheid wat kenmerkend van Petrus was, wat van hom 'n maklike prooi van die satan gemaak het.

Die apostels se enigste hoop om die komende beproewing te deurstaan, is in gebed geleë (Mark. 14:38). Dit was juis hulle versuim om te bid - en in besonder dié van Petrus - wat gelei het 
tot hulle gedeeltelike afval. "But when Satan stands before God for the soul of man, it is ultimately not their prayers which are effective, but those of God's Son" (Goulder, 1994:735).

Kenmerkend van Lukas, voeg hy hierdie verwysing na Jesus se gebed in (wat nie in die ander Evangelies beskryf is nie). Deur Jesus se gebed word dit moontlik dat Petrus se geloof hom nie begewe nie, ten spyte van sy swakheid. Na die krisis van die verloëning van Petrus, of liewer Simon, en die kruis van Jesus, moet Petrus sy broers versterk om voort te gaan met die stryd wat dissipelskap vir hulle sal meebring. Petrus sou die instrument word van die "weerkragtig-worden" (Berkelbach van der Sprenkel, 1964:372) van die dissipels. Ook om in daardie stryd vol te hou, is die gebed onmisbaar. Deur gebed sou hulle kontak behou met die kragstroom van God.

\subsection{Lukas 22:39-46 (In Getsemane)}

\begin{abstract}
Toe Hy op die plek aankom, sê Hy vir hulle: "Bid dat julle nie in versoeking kom nie." Hy het Hom toe van hulle afgesonder omtrent so ver as 'n mens met 'n klip kan gooi. Daar het $\mathrm{Hy}$ gekniel en gebid: "Vader, as $U$ wil, neem tog hierdie lydensbeker van My af weg. Laat nogtans nie my wil nie maar u wil geskied!' 'n Engel uit die hemel het aan Hom verskyn en Hom versterk. Hy het in doodsangs geraak en het nog ernstiger gebid. Sy sweet het soos bloeddruppels geword wat op die grond val. Toe Hy van die gebed opstaan en by die dissipels kom, kry Hy hulle aan die slaap, uitgeput van droefheid. Hy sê toe vir hulle: "Waarom slaap julle? Staan op en bid, sodat julle nie in versoeking kom nie."
\end{abstract}

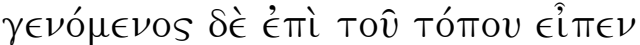

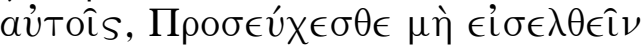

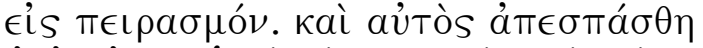

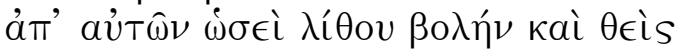

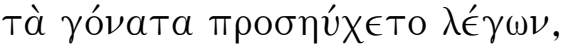

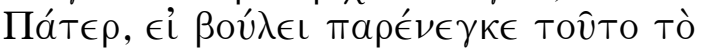

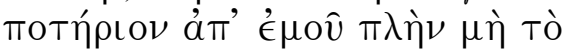

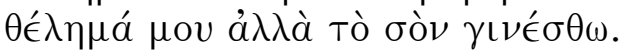

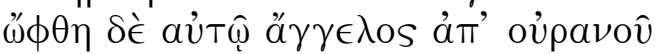

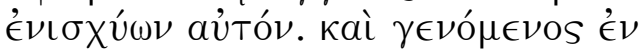

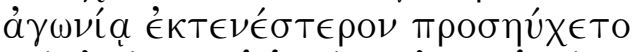

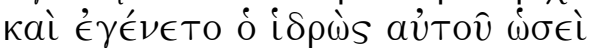

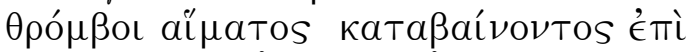

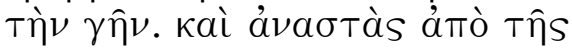

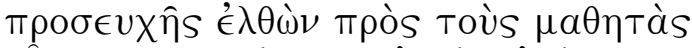

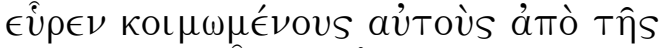

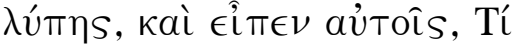

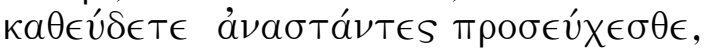

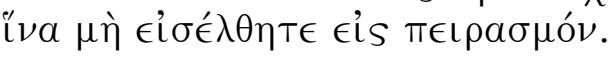

Al drie die Sinoptiese Evangelies berig dat Jesus in Getsemane gebid het. "Toen Jezus de zwaarte van de last van het kruislijden steeds duidelijker voelde, kon Hij alleen maar biddend deze last aanvaarden" (Versteeg, 1991:11). Lukas se weergawe dui egter op 'n groter intensiteit in sy gebed. Lukas bied wel 'n korter weergawe van hierdie gebeure as Markus (14:32-42). Lukas vat die drievoudige gebed volgens Markus saam in een, maak die verwysing na die dissipels meer algemeen, beskryf hulle swakheid 
minder eksplisiet, en verwyder die menslike angs van Jesus. Lukas voeg egter dan vers 43 en 44 by ('n engel uit die hemel het aan Hom verskyn en Hom versterk, waarna Hy in doodsangs geraak het en nog ernstiger gebid het dat sy sweet soos bloeddruppels geword het), waaruit die ontsettende intensiteit van sy gebed blyk. Lukas voeg ook by dat Jesus gekniel het. Lukas verwys telkens na so 'n gebedshouding in kontekste van besondere intensiteit (Nolland, 1993(b):1083). Hierbenewens plaas Lukas ook groter klem op Jesus se opdrag aan sy dissipels om te bid dat hulle nie in versoeking kom nie - aan die begin en aan die einde van die gedeelte (Lukas 22:40 en 46). Die gebed van Jesus in Getsemane antisipeer sy lyding, maar ook sy triomf oor die lyding.

Die versoeking van die dissipels word ook betrek by hierdie gebeure. Om 'n volgeling van Jesus te wees, impliseer versoeking, hoewel op 'n ander manier as dié van Jesus. Die gebed van Jesus berei sowel vir Jesus as sy dissipels voor vir die komende krisis (Groenewald, 1989:253; Han, 2000:685). Jesus is baie besorgd oor sy dissipels. Hy wys hulle daarop hoe belangrik gebed is om hulle staande te hou in die komende stryd. As Jesus self die gebed nodig het om daaruit krag te ontvang vir selfoorgawe, hoeveel te meer het sy dissipels gebed nodig om aan Hom getrou te bly, wanneer hulle sien hoe Hy oorgelewer word in die hande van sy teenstanders!

Die Heilige Gees word geïmpliseer deur die engel uit die hemel wat aan Jesus verskyn het en Hom versterk het (Smalley, 1973:66). Hieruit blyk weer Lukas se beklemtoning van die aktiwiteit van die Heilige Gees in antwoord op gebed.

Ook hierdie gebed staan in verband met die koms van die koninkryk van God. 'n Paar verse vantevore skryf Lukas "Net soos my Vader 'n koninkryk aan My bemaak het, so bemaak Ek 'n koninkryk aan julle, sodat julle in my koninkryk aan my tafel kan eet ..." (22:29-30). Die gebed is 'n belangrike element in die koms van die koninkryk.

Hierdie gebed bied nuwe insig op die verhouding tussen Jesus en God. Hy noem Hom "Vader" en soek die wil van sy Vader wat vir Hom 'n taak gegee het om te volvoer (Conn, 1972:291). In die Ou Testament en Joodse literatuur tussen die Ou- en Nuwe Testament bestaan daar 'n huiwering om na God as Vader te verwys - en veral nie in gebed nie. 'Het woord 'Vader' dat in het Oude Testament nergens gebruikt wordt om in het gebed God aan te spreken nam Jezus bij zijn gebeden als hét woord in zijn mond" (Versteeg, 1991:15). Hieruit blyk die unieke verhouding waarin Jesus tot God staan en dat die beloofde heilstyd in Jesus 'n werklikheid geword 
het. Die Ou Testament beskryf die heilstyd immers as die tyd waarin God as Vader aangespreek sou word: "Ek het gesê: Noem My 'Vader', en moet nooit weer van My af wegdraai nie" (Jer. 3:19); "In trane sal hulle kom, met smeekgebede ... want Ek het Israel se Vader geword" (Jer. 31:9).

\subsection{Lukas 23:34 en 46 (Aan die kruis)}

Hoewel al vier die Evangelies verwys na die woorde van Jesus aan die kruis, is dit net Lukas wat die woorde van sy smekings as sodanig weergee (vgl. Marsh \& Moyise, 1999:45).

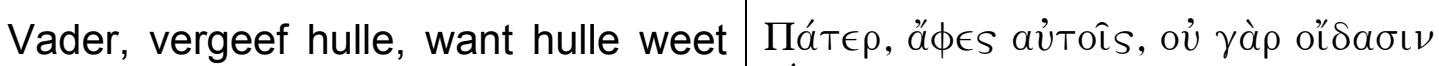

$$
\begin{aligned}
& \text { nie wat hulle doen nie! }
\end{aligned}
$$

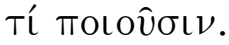

Die eerste en die laaste van die drie kruiswoorde wat deur Lukas opgeteken is, spreek van "Vader" en is gebede. Hierdie aanspreekvorm tipeer Jesus soos Lukas Hom sien: die middelaar tussen God en die mens, wie se opdrag dit is om vergewing te bedien. Die tot inkeer kom van die een misdadiger wat saam met Jesus gekruisig is, kan gesien word as reeds 'n verhoring van hierdie gebed (Viljoen, 1996:18).

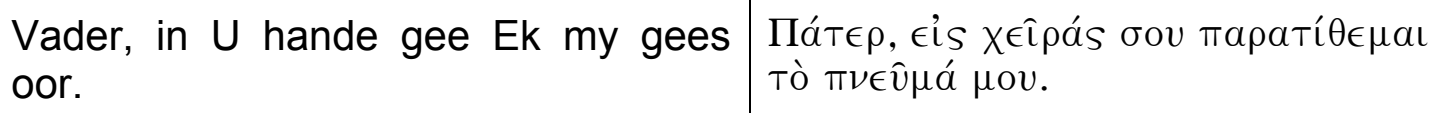

Die laaste kruiswoord van Jesus verwoord sy gebed van vertroue. Dit is nie 'n uitroep van angs en onsekerheid nie. Dit is 'n vredevolle verklaring dat $\mathrm{Hy}$ sy werk voltooi het (Viljoen, 1996:65). Hierdie woorde is ontleen aan Psalm 31:6 ("In u hande gee ek my lewe oor") en was die woorde wat van kleins af deel was van die aandgebed van 'n vroom Jood (Berkelbach van der Sprenkel, 1964:397; Groenewald, 1989:269). Met hierdie woorde vertrou hy hom aan God toe, en sien hy uit na die ontwaking in die nuwe lewensdag na die donker nag verby is.

Soos dit kenmerkend is van Lukas, staan hierdie gebede van Jesus ook binne konteks van die koms van die koninkryk van God. Volgens Lukas 23:39-43 word die regering van Jesus in die koninkryk deur die misdadiger bely. Die pleit van die misdadiger ("Jesus, dink aan my as $u$ in u koninkryk kom") herinner aan Psalm 106:4 ("Dink aan my, Here, in u liefde vir u volk"). Volgens oorlewering het vroom Jode hierdie bede op hulle sterfbed uitgespreek (Groenewald, 1989:268). Dit is nou ook die sterwensbede van die misdadiger. Hy rig hom egter nie tot God nie, 
maar tot Jesus. Hy glo dat Jesus die brenger is van die koninkryk van God, en dat Hy genadig is om aan die sondaar te dink. In antwoord op die misdadiger se versoek, verseker Jesus hom dat hy dadelik in die paradys opgeneem sal word. Direk na die dood van Jesus volg sy intrede in die verblyfplek van die geluksaliges. Terwyl die misdadiger die parousia in die ongespesifiseerde toekoms verwag, gun Jesus die toegang "vandag" (Viljoen, 1996:21).

\section{Gevolgtrekking}

Gebed speel 'n belangrike tema in die Lukaanse geskrifte. Dit blyk uit die terminologie wat gebruik is, asook uit die konteks waarbinne dit gebruik is.

Verwysing na gebede in die Lukas-evangelie handel enersyds oor gebede van mense en andersyds oor die gebede van Jesus self. Hierbenewens bied Lukas ook 'n uitgebreide bespreking van Jesus se onderrig oor gebed aan sy volgelinge. Hierdie artikel behandel slegs die gebede van Jesus.

Pogings om die doel van die gebede van Jesus tot een motief te reduseer, is eensydig en reduksionisties. Jesus se lewe op aarde openbaar 'n voortdurende vertroue op God in die hantering van versoeking en die volharding in geloof. Jesus verwys elke aspek van sy lewe tot God en sy verlossingswil. Tog blyk dit dat veral twee oorkoepelende motiewe sterk op die voorgrond tree, naamlik die heilshistoriese en didaktiese. Die sorgvuldige rangskikking van gebedstekste, wat die volhardende gebedslewe van Jesus beklemtoon, maak dit duidelik.

Gebed figureer by keerpunte in die lewe van Jesus, naamlik by sy doop, die roeping van die twaalf, die belydenis van Petrus, die berg van verheerliking, Getsemane en aan die kruis. Dit is gebruiklik dat Lukas gebedstekste verbind met prominente heilshistoriese momente en krisisse in die lewe van Jesus. Lukas voer aan dat God deur gebed die bediening van Jesus gelei het. Die gebede bevestig dat Jesus voortgaan met sy bediening en dat Hy sy werk sal voltooi. Dit is plegtige handelings van Jesus om sy lewe op die wil van God te fokus. Alles wat Jesus tydens sy omwandelinge op aarde gedoen het, word gedra deur gebed.

Al Jesus se gebede is met die kruis geassosieer, waarin die heilsgeskiedenis sy hoogtepunt bereik en die Koninkryk van God gevestig word. Die doel van die kruis is om die koms van die koninkryk van God te laat realiseer (9:28-36; 22:39-46). 
Lukas beskou smeekgebede as die manier waarop die dinamiese krag van God se Gees realiseer vir die doel van verlossing. Voorts beskou Lukas die aktiwiteit van die Heilige Gees in Jesus as die koms van die koninkryk. Waar die Gees is, daar is die koninkryk. God se eskatologiese heerskappy word bemiddel en gekarakteriseer deur die Heilige Gees, van Wie Jesus par excellance die draer is. Volgens Lukas is die voorbereiding van Jesus vir sy bediening en die voortgang daarvan gekenmerk deur die aktiewe teenwoordigheid van die Heilige Gees. Op so 'n manier word die teenwoordigheid van die koninkryk in die geskiedenis gerealiseer.

Met Jesus se gebede het 'n nuwe manier van bid tot stand gekom. Waarna die profete uitgesien het - die tyd dat God as "Vader" aangespreek sou word - het in Jesus tot vervulling gekom. Op grond van die unieke verhouding tussen Jesus en die Vader (10:2122), bewerk Jesus versoening tussen God en die mens. Versoende mense kan God nou ook as "Vader" aanspreek.

Lukas verbind Jesus se gebede met dissipelskap (6:12; 9:23-25; $9: 28-36 ; 22: 32 ; 22: 39-46)$. Soos Jesus Homself deur gebed voorberei op die kruis, moet sy volgelinge voortgaan om te bid ter wille van hulle diens in die koninkryk, in die tyd na die opstanding en hemelvaart tot en met die wederkoms). Van die gebedslewe van die vroeë kerk bied Lukas 'n unieke beskrywing in sy tweede boek, Handelinge. Die gebede van Jesus het daarom ook 'n didaktiese betekenis om aan die vroeë kerk leiding te gee oor die betekenis en inhoud van die gebed, sodat hulle kan volhard in hulle roeping in die koninkryk. Jesus se gebede het egter die kerk se gebede geïnisieer, sodat gelowiges Hom kan navolg met gebed.

Jesus het immers gebid om Homself en sy dissipels voor te berei vir die kruis en om die koninkryk te laat kom. Daarom dring Jesus by sy dissipels aan om te bid, sodat hulle kan volhou in hulle volgelingskap. Jesus se gebedslewe word deurgaans verbind aan die feit dat Hy sy kruis sal moet opneem. Om 'n volgeling van Jesus te wees, sal sy dissipels ook moet volhard in hulle gebed.

Soos die voorbeelde van Jesus se gebede 'n didaktiese doel vir die vroeë kerk gedien het, is dit ook vir die kerk van vandag toepaslik.

\section{Geraadpleegde bronne}

BERKELBACH VAN DER SPRENKEL, S.F.H.J. 1964. Het evangelie van Lukas. 's-Gravenhage: Boekencentrum.

BLOMBERG, C.L. 2002. Jesus and the Gospels. An introduction and survey. Leicester: Apollos. 
CARSON, D.A., MOO, D.J. \& MORRIS, L. 1992. An introduction to the New Testament. Grand Rapids: Zondervan.

CONN, H.M. 1972. Luke's theology of Prayer. Christianity Today, 17(22):290292.

DANKER, F.W. 1988. Jesus and New Age: A commentary on St. Luke's Gospel. Philadelphia: Fortress.

DUNN, J.G. 1970-71. Spirit and kingdom. Expository Times, 82:36-40.

ELLIS, E.E. 1966. The Gospel of Luke. London: Oliphants.

FLOOR, L. 1988. Persoon en werk van de Heilige Geest. Kampen: Kok.

GROENEWALD, E.P. 1989. Die evangelie volgens Lukas. Kaapstad: NG Kerkuitgewers.

GOULDER, M.D. 1994. Luke. Journal of the Study of the New Testament. Supplement series 20. Sheffield: Sheffield Academic Press.

HAN, K.S. 2000. Theology of prayer in the Gospel of Luke. Journal of the Evangelical Theological Society, 43(4):675-693.

HARRIS, L.O. 1966. Prayer in Luke-Acts: A study in the theology of Luke. Nashville: Vanderbilt University. (Ph.D. dissertation.)

KLOSTERMANN, E. 1929. Das Lukasevangelium. Tübingen: Mohr.

LAMPE, G.W.A. 1955. The Holy Spirit in the writings of St. Luke. (In Nineham, D.E., ed. Studies in the Gospels. Essays in memory of R.H. Lightfoot. Oxford: University Press. p. 168-182.)

MARSH, C. \& MOYISE, S. 1999. Jesus and the Gospels. London/New York: Cassel.

MARSHALL, I.H. 1978. The Gospel of Luke: A commentary on the Greek text. Grand Rapids: Eerdmans.

MORRIS, L. 1990. New Testament theology. Michigan: Grand Rapids.

NOLLAND, J. 1989. Word Biblical commentary. Volume 35A. Luke 1-9:20. Dallas: Word Books.

NOLLAND, J. 1993(a). Word Biblical commentary. Volume 35B. Luke 9:2118:34. Dallas: Word Books.

NOLLAND, J. 1993(b). Word Biblical commentary. Volume 35C. Luke 18:3524:53. Dallas : Word Books.

O'BRIEN, P.T. 1973. Prayer in Luke-Acts. Tyndale Bulletin, 24:111-127.

OTT, W. 1965. Gebet und Heil: Bedeutung der Gebetsparänese in der lukanischen Theologie. München: Kösel.

PLUMMER, A. 1896. A critical and exegetical commentary on the gospel according to Luke. Edinburgh: Clark.

RENGSTORF, K.H. 1965. Das Evangelium nach Lukas. Göttingen: Vandenhoeck \& Ruprecht.

SCHEFFLER, E.H. 1991. Die teologie van die Lukasevangelie in konteks: Bevryding uit lyding. (In Roberts, J.H. et al., reds. Teologie in konteks. Halfway House: Orion. p. 62-92.)

SMALLEY, S.S. 1973. Spirit, kingdom and prayer in Luke-Acts. Novum Testamentum, 15(1):59-71.

SNYMAN, W.J. 1977. Nuwe en ou dinge. Potchefstroom: Pro Rege.

TUCKETT, C.M. 2001. Luke. (In McKnight, S., ed. The Synoptic Gospels. Sheffield: Sheffield Academic Press. p. 252-342.)

VAN BRUGGEN, J.J. 1996. Lucas. Het evangelie als voorgeschiedenis. Kampen: Kok. 
VERSTEEG, J.P. 1988. De Heilige Geest en Christus. (In Coetzee, J.C., red. Koninkryk Gees en Woord. Huldigingsbundel aangebied aan prof. dr. Lambertus Floor. Pretoria: NG Kerkboekhandel. p. 309-319.)

VERSTEEG, J.P. 1991. Het gebed volgens het Nieuwe Testament. Amsterdam: Buijten \& Schipperheijn.

VILJOEN, F.P. 1996. Die sewe kruiswoorde. George: Outennuut.

VILJOEN, F.P. 2002. Mark, the Gospel of the suffering Son of Man: An encouragement directed to a despondent religious minority in the city of Rome. In die Skriflig, 36(3):455-474.

VILJOEN, F.P. 2003. Luke, the Gospel of the Saviour of the world. Nederduits Gereformeerde Teologiese Tydskrif, 44(1 \& 2):199-209.

WON, P.H. 1999. Lucan pneumatology: The work of the Holy Spirit through prayer in Luke-Acts. Potchefstroom: PU vir CHO. (Dissertation - Th.M.)

\section{Kernbegrippe:}

gebed en die Heilige Gees

gebed en die koms van die Koninkryk

gebed in die Lukas-evangelie

gebed van Jesus

\section{Key concepts:}

prayer and the coming of the Kingdom

prayer and the Holy Spirit

prayer in Luke's Gospel

prayer of Jesus 
